Article

\title{
Demonstrating the Effect of Precipitation on the Mechanical Stability of Fine-Grained Austenite in Reversion-Treated 301LN Stainless Steel
}

\author{
Antti Järvenpää ${ }^{1, *}$, Matias Jaskari ${ }^{1} \mathbb{C}^{\mathbb{O}}$, Timo Juuti $^{2}$ and Pentti Karjalainen ${ }^{2}$ \\ 1 Kerttu Saalasti Institute, Future Manufacturing Technology Group, University of Oulu, Pajatie 5, \\ FI-85500 Nivala, Finland; matias.jaskari@oulu.fi \\ 2 Centre for Advanced Steels Research, Materials and Production Engineering Unit, University of Oulu, \\ P.O. Box 4200, FI-90014 Oulu, Finland; timo.juuti@oulu.fi (T.J.); pentti.karjalainen@oulu.fi (P.K.) \\ * Correspondence: antti.jarvenpaa@oulu.fi; Tel.: +358-44-5551633
}

Received: 2 August 2017; Accepted: 31 August 2017; Published: 4 September 2017

\begin{abstract}
According to recent investigations, a huge difference exists in the mechanical stability of austenite between the grain-refined structure states obtained in reversion annealing at $800-700{ }^{\circ} \mathrm{C}$ or at $900{ }^{\circ} \mathrm{C}$, in a 301LN type austenitic stainless steel. Precipitation of chromium nitride occurring at these lower temperatures has been argued to be the factor reducing the stability. To prove this argument, a fine-grained, very stable austenitic structure was created at $900{ }^{\circ} \mathrm{C}$ in $1 \mathrm{~s}$, and subsequently annealed at lower temperatures between 850 and $750{ }^{\circ} \mathrm{C}$, up to $1000 \mathrm{~s}$. It was found that the subsequent annealing at 750 and $800{ }^{\circ} \mathrm{C}$ resulted in prominent gradual decrease of the mechanical stability under tensile straining, detectable after $10 \mathrm{~s}$ annealing duration and continued until $1000 \mathrm{~s}$. Only minimal grain growth occurred, which decreased the stability very marginally. The degree of the stability drop followed the predicted kinetics of the $\mathrm{Cr}_{2} \mathrm{~N}$ precipitation with regards as its dependence on annealing duration and temperature. Further, the tensile yield strength of the fine-grained structure increased slightly due to the annealing. The presence of nano-sized $\mathrm{Cr}_{2} \mathrm{~N}$ particles was verified after $1000 \mathrm{~s}$ holding at $750^{\circ} \mathrm{C}$. These observations and predictions yield firm evidence for the imperative contribution of precipitation to the highly reduced mechanical stability of grain-refined austenite in this steel.
\end{abstract}

Keywords: austenitic stainless steel; refined grain size; austenite stability; annealing; precipitation; deformation induced martensite

\section{Highlights}

- Mechanical stability of fine-grained austenite decreases gradually during annealing at $750-800{ }^{\circ} \mathrm{C}$.

- Nano-size $\mathrm{Cr}_{2} \mathrm{~N}$ precipitation occurs in austenite during annealing at $750-800{ }^{\circ} \mathrm{C}$.

- The degree of stability drop follows the predicted kinetics of the precipitation.

\section{Introduction}

Deformation-induced martensite transformation (DIM) plays a significant role in metastable austenitic steels with regards to their static and dynamic mechanical properties, e.g., [1-4]. In a broader view, the transformation induced plasticity (TRIP) effect is also a key phenomenon concerning the enhanced properties of the third generation steels with the submicron-grained retained austenite phase [5-7]. The mechanical stability of austenitic stainless steels, i.e., susceptibility of austenite to martensite transformation, is influenced by many factors, e.g., chemical composition, temperature, grain crystallographic orientation, defect density, surrounding phases and grain size, e.g., [5-8]. 
Nitrogen is a strong austenite stabilizer and it improves the mechanical properties and corrosion resistance of austenitic stainless steels, and high-nitrogen austenitic stainless steels have been developed for their utilization. Simmons [9] has presented an overview of high-nitrogen steels, and more recently Lo et al. [3] and Machado et al. [10] have reviewed the role of nitrogen in iron-based alloys. It has been well known for decades that nitrogen alloying increases the mechanical stability of austenitic stainless steels, the stability being equal to [11,12] or stronger [13] than that of carbon. This influence has been presented in well-known regression equations for the deformation temperature where a certain fraction of DIM has formed at a given strain [11,12], the equations reviewed by Padilha et al. [2] and Lo et al. [3]. In high-nitrogen steels, the formation of DIM becomes restricted, even at cryogenic temperatures [14].

It is commonly reported that with decreasing grain size (GS), the mechanical stability of austenite increases $[8,15,16]$. Järvenpää et al. have studied the effect of GS on austenite stability in reversion-treated grain-refined structure of a Type $301 \mathrm{LN}$ steel $(18 \mathrm{Cr}-7 \mathrm{Ni}-0.15 \mathrm{~N})$ under tensile straining [17] and cyclic loading [18]. They observed that the highest austenite stability existed with an average GS of 1-2 $\mu \mathrm{m}$, whereas the stability was lower with both increasing and decreasing average GS. A similar dependence has been reported a few times previously [19-22]. A submicron grain size causing the change in the nucleation sites of DIM was suggested to be the reason for the stability drop with decreasing GS $[19,21]$. However, Järvenpää et al. $[17,18]$ demonstrated that the GS was not a relevant factor for explaining the inverse trend in austenite stability in this steel, and in fact the submicron-size grains seemed to be quite stable. Instead, it was argued that precipitation of $\mathrm{CrN}$ at lower reversion annealing temperatures of $800-700^{\circ} \mathrm{C}$ where still finer submicron-grained structures are created, reduces the austenite stability.

The thermal instability of the structure in nitrogen-alloyed stainless steels is well known, as nitrogen tends to precipitate out of the solid solution of austenite $[2,3,14]$. In high-nitrogen steels, the precipitation of $\mathrm{Cr}_{2} \mathrm{~N}$ has been found to occur over a temperature regime of $600-1050{ }^{\circ} \mathrm{C}$, sometimes starting at grain boundaries, followed by discontinuous precipitation (cellular phase formation), and finally taking place intragranularly within the matrix. The precipitation kinetics vary highly depending on alloy composition and temperature, being primarily controlled by $\mathrm{Cr}$ diffusion, e.g., $[9,10,14,23]$. In certain alloys, the fastest kinetics can exist at $800^{\circ} \mathrm{C}$ [23]. However, the data available in the literature are generally for alloys with higher nitrogen contents than in the present $301 \mathrm{LN}$ steel.

Rajasekhara et al. [24,25] observed the precipitation of $\mathrm{CrN}$ during the reversion treatments in a 301LN steel; those results were earlier adopted as an evidence for the fast nitride precipitation and its temperature dependence without repeating transmission electron microscopy (TEM) examinations $[17,18]$. However, to provide further proof of this very essential feature concerning the behavior of reversion-treated, grain-refined 301LN N-bearing steel, the present paper focuses on demonstrating the effect of precipitation on the mechanical stability of the fine-grained austenite. The hypothesis is that in the course of low temperature annealing, the stability of the fine-grained structure, which is in the most stable state due to the micron-scale grain size created at $900{ }^{\circ} \mathrm{C}$ and the absence of precipitation, will gradually decrease while precipitation occurs.

\section{Experimental Methods}

\subsection{Test Material}

The test material was a commercial austenitic $18 \mathrm{Cr}-7 \mathrm{Ni}-0.15 \mathrm{~N}$ stainless steel of Type $301 \mathrm{LN}$, received from Outokumpu Stainless Oy, Tornio, Finland, as an $8 \mathrm{~mm}$ hot rolled and annealed sheet. The chemical composition determined at the company using an ARL 4460 optical emission and ARL 9800 XP X-ray spectrometer is given in Table 1. The sheet was cold rolled to $3 \mathrm{~mm}$ final thickness in a laboratory rolling mill, so that the total cold rolling thickness reduction was $63 \%$. Temperature during the cold rolling was kept below $50^{\circ} \mathrm{C}$ by cooling the sheets in a liquid nitrogen atmosphere between the 
rolling passes. In the cold-rolled state, the fraction of deformation-induced ferromagnetic $\alpha^{\prime}$-martensite (i.e., DIM) was $96 \%[12,13]$.

Table 1. Chemical composition (wt \%) of the test material.

\begin{tabular}{ccccccccccccc}
\hline $\mathbf{C}$ & $\mathbf{S i}$ & $\mathbf{M n}$ & $\mathbf{P}$ & $\mathbf{S}$ & $\mathbf{C r}$ & $\mathbf{N i}$ & $\mathbf{M o}$ & $\mathbf{C u}$ & $\mathrm{Al}$ & $\mathbf{O}$ & $\mathbf{N}$ & $\mathbf{F e}$ \\
\hline 0.025 & 0.53 & 1.25 & 0.024 & 0.001 & 17.5 & 6.5 & 0.09 & 0.20 & 0.014 & 0.0038 & 0.150 & balance \\
\hline
\end{tabular}

\subsection{Annealing Experiments}

Rectangular pieces were cut from the cold-rolled sheet transverse to the rolling direction. The pieces were heat treated on a Gleeble 3800 thermo-mechanical simulator (Dynamic Systems Inc., Poestenkill, NY, USA) before machining specimens for mechanical testing and microscopy. A high heating rate of $200{ }^{\circ} \mathrm{C} / \mathrm{s}$ and cooling rate of $35^{\circ} \mathrm{C} / \mathrm{s}$ was used. The effect of a high heating rate on the reversion mechanism in metastable cold-rolled austenitic steels has been investigated, e.g., [26,27]. It is also known that ultrahigh heating rates can result in grain size refinement and improved formability in low carbon steels, see e.g., [28]. The annealing temperature of $900{ }^{\circ} \mathrm{C}$ ( $1 \mathrm{~s}$ holding) was used to create a fine-grained austenitic structure, coded here as $900 / 1$. This structure is the most stable among the reversion-treated structures investigated earlier $[17,18]$. These $900 / 1$ samples were subsequently heated up and held at $750{ }^{\circ} \mathrm{C}$ for 10,100 or $1000 \mathrm{~s}$, the structures being coded as 900/1-750/10, 900/1-750/100 and 900/1-750/1000, respectively (Table 2). Precipitation kinetics is dependent on the annealing temperature. Hence, to obtain further data and proof of the occurrence of precipitation, two other annealing temperatures of 800 and $850{ }^{\circ} \mathrm{C}$ were used for the duration of $100 \mathrm{~s}$, the samples being coded as 900/1-800/100 and 900/1-850/100, respectively. Data for the 800/1 and 900/1 structures, called earlier as ultrafine-grained and fine-grained austenitic structures (coded then as UFGA and FGA respectively $[17,18])$, were taken from the previous experiments. Their processing conditions are also included in Table 2.

Table 2. Temperatures and soaking times for creating the studied microstructures.

\begin{tabular}{lccccccc}
\hline Annealing parameter & $\mathbf{8 0 0 / 1}$ & $\mathbf{9 0 0 / 1}$ & $\mathbf{9 0 0 / 1 - 7 5 0 / 1 0}$ & $\mathbf{9 0 0 / 1 - 7 5 0 / 1 0 0}$ & $\mathbf{9 0 0 / 1 - 7 5 0 / 1 0 0 0}$ & $\mathbf{9 0 0 / 1 - 8 0 0 / 1 0 0}$ & $\mathbf{9 0 0 / 1 - 8 5 0 / 1 0 0}$ \\
\hline Max. temperature $\left({ }^{\circ} \mathrm{C}\right)$ & 800 & 900 & $900+750$ & $900+750$ & $900+750$ & $900+800$ & $900+850$ \\
Time (s) & 1 & 1 & $1+10$ & $1+100$ & $1+1000$ & $1+100$ & $1+100$ \\
\hline
\end{tabular}

\subsection{Tensile Testing}

The heat-treated pieces were machined to the final dimensions for tensile tests. The width of the gauge section was $10 \mathrm{~mm}$ and the length was $25 \mathrm{~mm}$ for all specimens. Tensile straining was performed in a Zwick100 tensile testing machine equipped with an extensometer. A low strain rate $\left(0.0005 \mathrm{~s}^{-1}\right)$ was applied to avoid adiabatic heating.

\subsection{Microstructure Examinations}

The evolution of the ferromagnetic $\alpha^{\prime}$-martensite fraction, i.e., DIM, was determined during interrupted tensile tests by using a Feritscope instrument (Feritscope FMP30, Helmut Fischer GmbH Institut für Elektronik und Messtechnik, Sindelfinge, Germany), including a correction factor of 1.7, as specified by Beese and Mohr [29] and Talonen et al. [30,31]. This method was commonly adopted in earlier research $[17-21,32]$. The magnetic measurement was preferred to the electron backscatter diffraction (EBSD, Carl Zeiss AG, Oberkochen, Baden-Württemberg, Germany) method due to a considerable local variation of the martensite fraction. The volume fraction of nonmagnetic $\varepsilon$-martensite was always supposed to be low (few percents maximum), as earlier observed in tensile testing [19,31] as well as in the stress-controlled fatigue testing of this steel [32].

Metallographic specimens were fine-ground (600 grit) and electropolished before final chemical polishing with $0.05 \mu \mathrm{m}$ colloidal silica suspension to avoid any martensite transformation on the 
surface during sample preparation. To determine the GS of various microstructures, specimens were examined using the EBSD method (at $15 \mathrm{kV}$ with an aperture $120 \mu \mathrm{m}$, working distance 10-12 mm and the minimum step size of $0.03 \mu \mathrm{m}$ ). An area of $10,000 \mu^{2}$ was covered in each measurement, including 5000 grains at the minimum.

For transmission electron microscopy, the specimen were mechanically ground to $80 \mu \mathrm{m}$ thickness, and then the punched $3 \mathrm{~mm}$ circular disks were electropolished by the twin-jet method in a $10 \%$ perchloric acid-methanol-butanol solution with a TenuPol-5 apparatus using $32 \mathrm{~V}$. The thin foils were examined in a Jeol JEM-2200FS STEM (JEOL Ltd, Akishima, Kantō, Japan) at 200 kV with an EDS unit, and nanobeam diffraction was used to identify the precipitates.

\subsection{Modelling of Equilibrium Phase Structure and Precipitation Kinetics}

A Thermo-Calc software package with a precipitation module TC-Prisma (based on the CALPHAD method) was employed for thermodynamic modeling for the prediction of the equilibrium phase diagram of the studied steel, and the kinetics of the nitride precipitation in the steel. The calculations were carried out using a TCFE7 thermodynamic database for Fe-based alloys and a kinetic database of MOBFE2 containing the mobility data for Fe-based alloys. The TC-Prisma simulated the nucleation, growth, and coarsening of precipitates using the Langer-Schwartz theory and the Kampmann-Wagner numerical approach, in conjunction with Thermo-Calc and the diffusion module (DICTRA) [33].

\section{Results and Discussion}

\subsection{Grain Structure of Annealed Samples}

All annealed structures were fully austenitic. The average austenite GSs with the standard deviations determined by EBSD are given in Table 3. In the first column they are based on both low angle and high angle grain boundaries (LAGB, misorientation $<15^{\circ}$ and HAGB, respectively), and in the right column, based on HAGBs only. This data has been reported earlier for reversion-treated 800/1 and 900/1 structures [17], but is shown here for comparison. As intended, the reversed 900/1 structure and subsequently annealed structures were fine-grained, exhibiting grains of a few microns in size. The 800/1 structure was even finer, with the grain size below one micrometer. The grain growth at the annealing temperatures was slight, and its consequences will be discussed in Section 3.3.

Table 3. Grain sizes and standard deviations of the studied structures.

\begin{tabular}{ccccc}
\hline \multirow{2}{*}{ Code } & \multicolumn{4}{c}{ Grain Size $[\mu \mathrm{m}]$} \\
\cline { 2 - 5 } & LAGB & S.D. & HAGB & S.D. \\
\hline $800 / 1$ & 0.5 & 0.2 & 0.6 & 0.6 \\
$900 / 1$ & 1.3 & 0.4 & 1.4 & 1.4 \\
$900 / 1-750 / 1000$ & 1.6 & 0.5 & 1.7 & 1.0 \\
$900 / 1-800 / 100$ & 1.7 & 0.5 & 1.9 & 0.9 \\
$900 / 1-850 / 100$ & 2.2 & 0.9 & 2.4 & 2.0 \\
\hline
\end{tabular}

LAGB, low angle grain boundary $\left(<15^{\circ}\right)$; HAGB, high angle grain boundary; S.D., Standard deviation.

\subsection{Austenite Stability}

The $\alpha^{\prime}$-martensite (DIM) fraction was measured on-line by interrupting the test at certain strains without unloading the specimen. It must be noticed that due to the Villari effect, the DIM values were obviously somewhat underestimated [29], but because the load levels at a given strain were almost equal for all the annealed structures (see the flow stresses in Section 3.4), the relative order would be the same as if the specimens were unloaded. As evident from Figures 1 and 2, the fine-grained $900 / 1$ structure was most stable among the tested structures, whereas the submicron-grained $800 / 1$ structure was the most unstable. The difference between them was very significant, as reported 
earlier $[17,18]$. However, a distinct evolution in the DIM fraction caused by the annealing of the 900/1 structure at $750{ }^{\circ} \mathrm{C}$ is seen in Figure 1a. The DIM fraction at a given strain increased, i.e., the high stability of the 900/1 structure diminished gradually with a prolonged annealing duration from 10 to $1000 \mathrm{~s}$. The stability was decreased slightly after $10 \mathrm{~s}$ and it reached a level equal to that of the $800 / 1$ structure after $1000 \mathrm{~s}$ of annealing. Annealing at $800^{\circ} \mathrm{C}$ for $100 \mathrm{~s}$ also decreased the stability, although slightly less than by the same duration at $750{ }^{\circ} \mathrm{C}$, but at $850{ }^{\circ} \mathrm{C}$ the influence was minimal, as shown in Figure $1 b$.

It can be noticed from Figure $1 \mathrm{a}$ that the stability change due to the annealing treatment was most evident at strains of $0.15-0.25$, the maximum being as high as $25 \%$ per unit between the $900 / 1$ and $900 / 1-750 / 1000$ structures. DIM seemed to saturate at the same level of about 0.8 in all structures, except in the 900/1 structure where DIM remained somewhat lower.

The transformation rates of DIM were predicted from the curves plotted in Figure 1, and they are shown in Figure 2. It is seen that the maximum in the transformation rate increased and shifted to smaller strains with prolonging annealing duration at the $750{ }^{\circ} \mathrm{C}$ (Figure 2a). This change also indicates the weakening stability as a result of the annealing. While holding at higher temperatures, the maximum transformation rate of DIM remained lower (Figure 2b). Annealing at $850{ }^{\circ} \mathrm{C}$ for $100 \mathrm{~s}$ had practically no effect on the transformation rate.
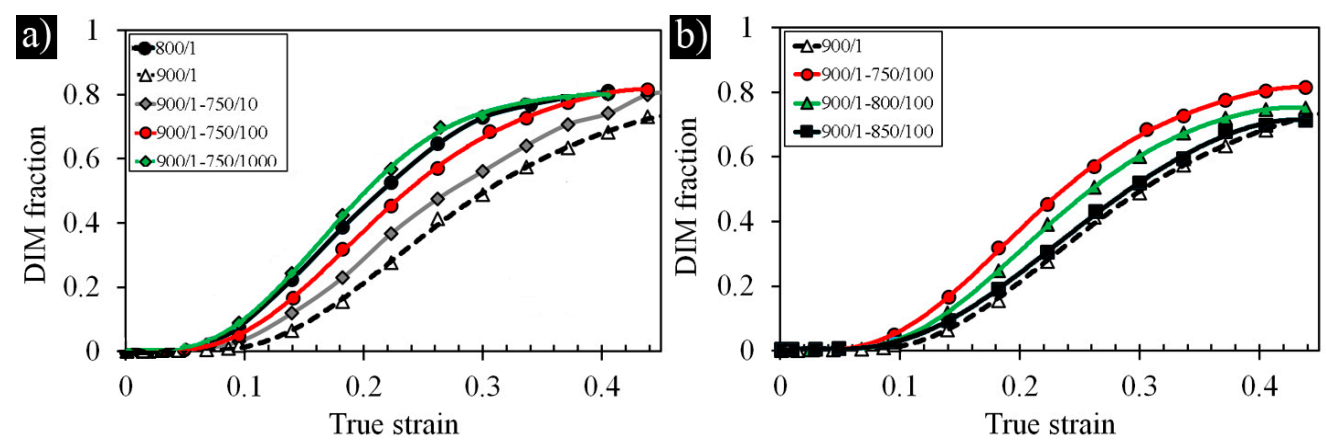

Figure 1. Evolution of the $\alpha^{\prime}$-martensite (DIM) fraction after different treatments. The $900 / 1$ state followed by annealing at (a) $750{ }^{\circ} \mathrm{C}$ for various durations $0-1000 \mathrm{~s}$ and (b) $750-850{ }^{\circ} \mathrm{C}$ for $100 \mathrm{~s}$.
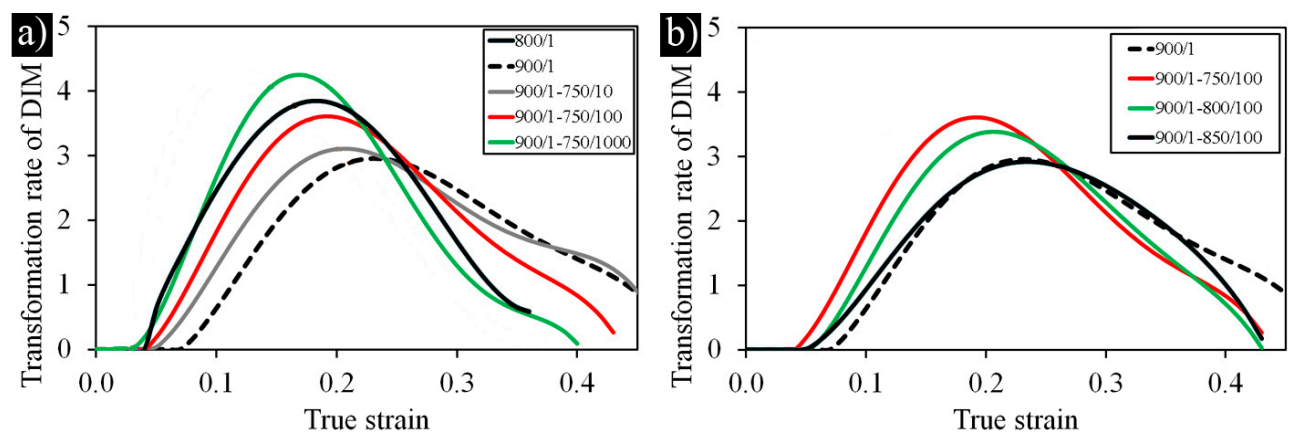

Figure 2. Evolution of transformation rate of DIM after different treatments. The 900/1 state followed by annealing at (a) $750{ }^{\circ} \mathrm{C}$ for various durations $10-1000 \mathrm{~s}$ and (b) $750-850{ }^{\circ} \mathrm{C}$ for $100 \mathrm{~s}$.

\subsection{Grain Coarsening}

As evident from Figure 1a, the austenite stability of the 900/1 structure decreased significantly with an increasing holding time at $750{ }^{\circ} \mathrm{C}$, and also as a result of annealing at $800{ }^{\circ} \mathrm{C}$. However, it might be argued that grain growth took place during these subsequent annealing stages and it reduced the stability. To check this option, grain sizes were measured by EBSD over areas including more than 5000 grains after the annealing treatments. Typical grain structures are displayed in Figure 3. 
The results show that the annealing at $750{ }^{\circ} \mathrm{C}$ for $1000 \mathrm{~s}$ increased the average GS of the $900 / 1$ structure very marginally, from 1.4 to $1.7 \mu \mathrm{m}$ (Table 3). In proportion, annealing at 800 and $850{ }^{\circ} \mathrm{C}$ for $100 \mathrm{~s}$ increased the average GS to 1.9 and $2.4 \mu \mathrm{m}$, respectively.

To determine the quantitative relationship between the austenite GS and its stability, i.e., DIM fraction at a given tensile strain, the data for the 900/1 structure was taken from Figure 1 and for the coarse-grained structures from the previous study [17]. These data are plotted in Figure 4. For further comparison, results from Marechal [19] for a similar grain-refined 301LN steel and Nohara [11] for a 301 stainless steel with coarse-grained structures were inserted. All the data reveal that the GS dependence of DIM can be expressed by the equations given in the figure, the slope of the logarithmic line being almost constant. The equations mean that the grain growth from 1.4 to $1.7 \mu \mathrm{m}$ would result in the increase of DIM of about $1 \%$ per unit, from $21 \%$ to $22 \%$ at the 0.20 strain, for instance. However, the difference in DIM fractions between the 900/1 and 900/1-750/1000 structures was about 25\% per unit, so that it could not be resultant from the grain growth, but caused by another phenomenon that was weakening the stability.

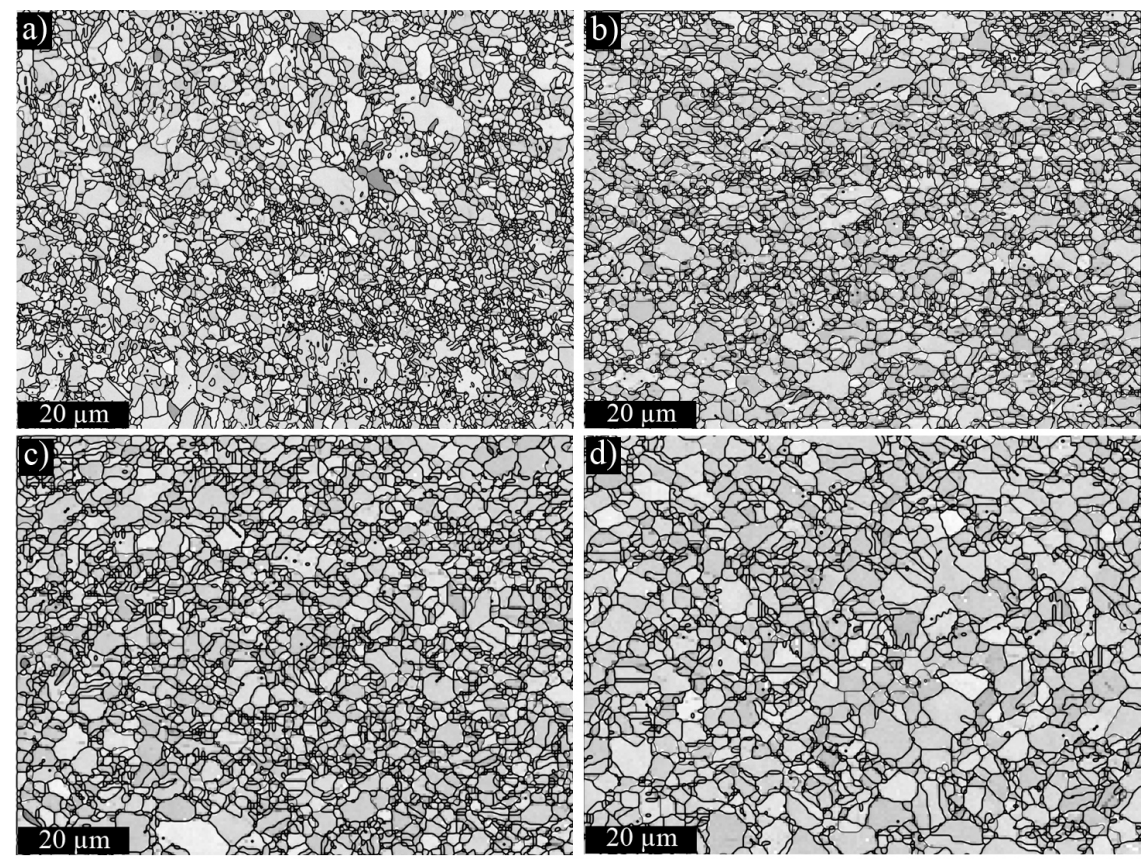

Figure 3. Grain structures of (a) 900/1, (b) 900/1-750/1000, (c) 900/1-800/100 and (d) 900/1-850/100 seen in superimposed electron backscatter diffraction (EBSD) band contrast and grain boundary maps (only HAGBs in black color exist). The rolling direction $\mathrm{x}$ normal direction plane views.

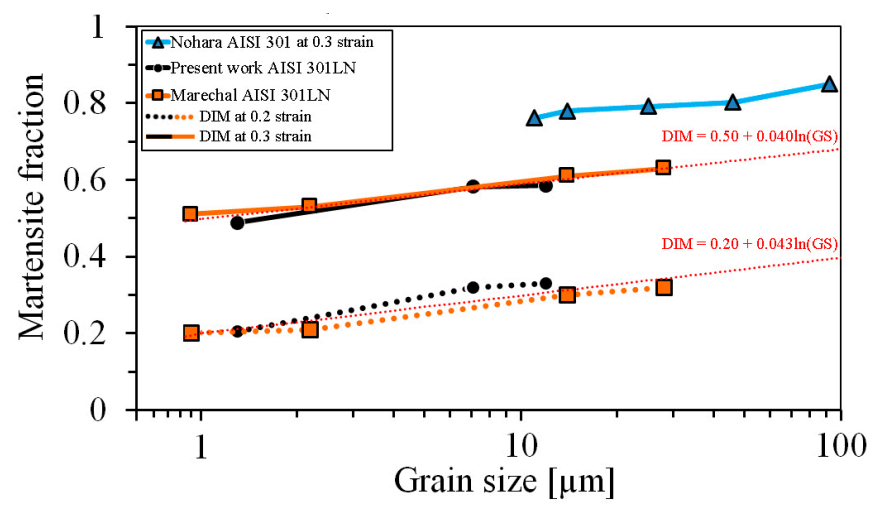

Figure 4. Effect of grain size (GS) on DIM fraction at 0.2 and 0.3 tensile true strains; data from $[11,17,19]$. 


\subsection{Flow Stress and Strain Hardening Behaviors Affected by Annealing}

By analyzing the shape of stress-strain curves it is possible to derive information about the phenomena occurred in the steel during the annealing stage. If precipitation had taken place, it should result in an increase of the yield strength, whereas grain coarsening would decrease it. The tensile flow stress and strain hardening curves are plotted in Figure 5a,b, respectively, and the tensile properties are listed in Table 4. The grain size refinement by reversion treatments has been shown in many papers to provide a significant enhancement of the strength $[17,19,20]$. The prominent increase was also evident here, as seen from the true stress-true strain curves in Figure 5a as comparing the 800/1 and 900/1 structures, as well as from the values of the tensile properties in Table 4 . The subsequent annealing of the $900 / 1$ structure at $750{ }^{\circ} \mathrm{C}$ had a much smaller influence, but from the insert in Figure $5 \mathrm{a}$ it can be noticed that the yield strength of 900/1-750/1000 was slightly higher (590 MPa) than that (550 MPa) of the $900 / 1$ structure. The higher yield strength must reflect the influence of precipitation strengthening.

Furthermore, it is seen in the insert that a stage of low strain hardening followed the yield point over the true strain range of $0.05-0.13$, while the flow stress of the $900 / 1-750 / 1000$ structure stayed lower than that of the $900 / 1$ structure. Later an inflection in the flow stress curve increased the flow stress curve again slightly above those of the 900/1, 900/1-750/10 and 900/1-750/100 structures. Also, the ductility became clearly reduced, seen in the comparison between the fracture elongations of the $900 / 1$ and $900 / 1-750 / 1000$ structures (67\% and 53\% respectively). Due to lower elongation, the ultimate tensile strength of the 900/1-750/1000 structure remained slightly lower than that of the $900 / 1$ structure (Table 4 ).
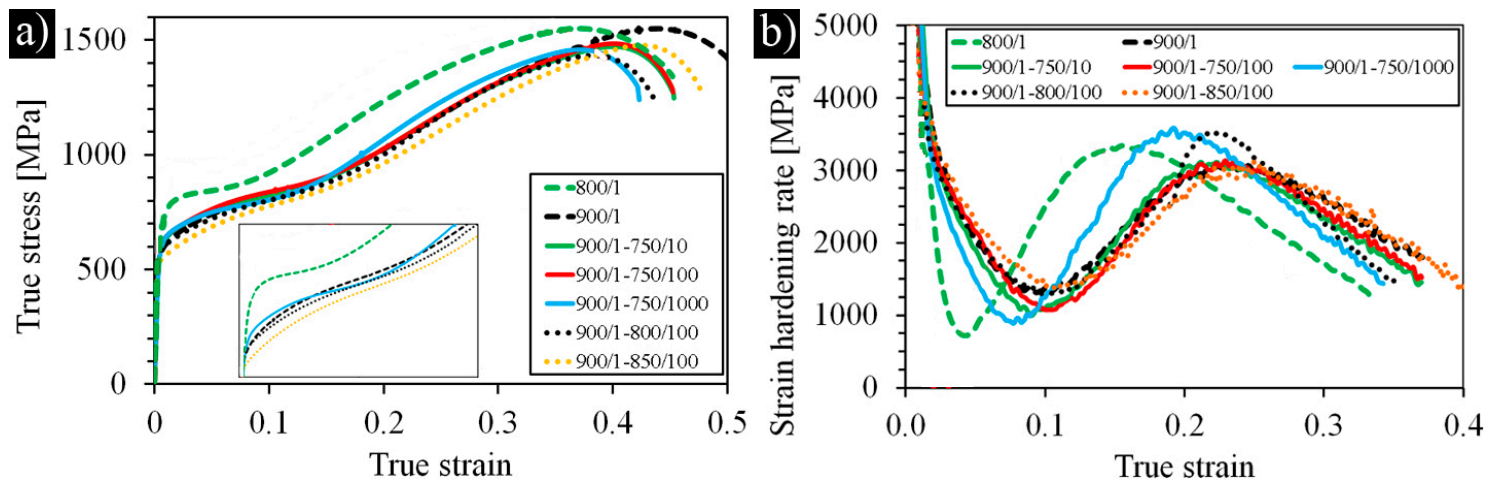

Figure 5. Tensile behaviors of the structures seen in (a) flow stress and (b) strain hardening rate curves.

Table 4. Tensile properties of the studied structures.

\begin{tabular}{cccccccccc}
\hline \multirow{2}{*}{ Code } & N & YS & YS S.D. & UTS & UTS S.D. & UEl & UEl S.D. & TEl & TEl S.D. \\
\cline { 2 - 10 } & \multicolumn{9}{c}{ (MPa) } \\
\hline $800 / 1$ & 3 & 750 & 12 & 1100 & 24 & 39 & 1.4 & 57 & 3.5 \\
$900 / 1$ & 3 & 550 & 5 & 1025 & 17 & 47 & & 67 & 2.7 \\
$900 / 1-750 / 1000$ & 3 & 590 & 7.9 & 1020 & 20 & 41 & 0.3 & 53 & 0.9 \\
$900 / 1-800 / 100$ & 3 & 580 & 24 & 990 & 30 & 45 & 1.6 & 59 & 1.8 \\
$900 / 1-850 / 100$ & 2 & 525 & 7.7 & 980 & 21 & 49 & 1.1 & 62 & 0.7 \\
\hline
\end{tabular}

$\mathrm{N}$, number of tests; S.D., standard deviation; YS, yield strength; UTS, ultimate tensile strength; UEl, uniform elongation; TEl, total elongation.

Certain differences can also be observed in the strain-hardening rate (SHR) vs. true strain curves plotted in Figure 5b. The initial slow hardening, appearing as a Luders strain in Figure 5a, is seen as a deep drop of the SHR at low strains. The drop was most prominent for the strongest $800 / 1$ structure, but less so for the $900 / 1-750 / 1000$ structure, whereas it was smallest for the 
$900 / 1$ structure. The 900/1-750/10 and 900/1-750/100 structures exhibited intermediate behaviors. The minimum SHR occurred with small strains in the same order (at strains from 0.015 to 0.1 ).

As discussed by Song et al. [34], the appearance of pronounced yield points and very long Luders strain regimes appear to be characteristics of ultrafine-grained steels and Al-alloys. These phenomena can be linked to an instantaneous low density of mobile dislocations and lack of dislocation sources within grains of ultrafine-grained alloys [34-36]. However, the annealing of the 900/1 structure at $750{ }^{\circ} \mathrm{C}$ could not refine the grain size, contrary to that, so that a finer grain size could not be a reason for the reduced strain hardening and enhanced Luders-type behavior of the 900/1-750/1000 structure. In an Al-Mg-Li alloy, the Luders-type behavior was detected in connection with precipitates [36] similar to an ultrafine-grained Fe-C alloy with carbide particles [35]. Hence, we can see here that softening and Luders-type elongation were present in the submicron-grained (800/1) structure and the annealed 900/1-750/1000 structure. They were even more pronounced in the partially reversed structures created at $700-750{ }^{\circ} \mathrm{C}$ [17]. Hence, we can suggest that the imposing softening and Luders-type elongation are a consequence of fine precipitates and interaction of dislocations with them, i.e., pinning effects, and not due to fine grain size itself.

\subsection{Modelling of Precipitation Kinetics}

To study and confirm the occurrence of nitride precipitation, the equilibrium structure of the present 301LN steel was predicted using a Thermo-Calc software. The equilibrium phase diagram including the major phases is shown in Figure 6. According to this, the precipitation of $\mathrm{Cr}_{2} \mathrm{~N}$ type particles could be expected at temperatures below about $920{ }^{\circ} \mathrm{C}$.

The precipitation kinetics of $\mathrm{Cr}_{2} \mathrm{~N}$, modeled by a TC-Prisma [33], can be seen in time-temperature-precipitation curves (TTP-curves) in Figure 7, in the instances of nucleation inside grains, at dislocations (a low density of $1 \times 10^{12} \mathrm{~m}^{-2}$ was assumed), or on grain boundaries (considering heterogeneous nucleation with GS of $1.4 \mu \mathrm{m}$ ). Typically, the interfacial energy of precipitates in steel is in the range of 0.1 to $0.5 \mathrm{~J} / \mathrm{m}^{2}$ [37]. However no value for $\mathrm{Cr}_{2} \mathrm{~N}$ was found in the literature, hence the interfacial energy of $0.1 \mathrm{~J} / \mathrm{m}^{2}$ was adopted, a value slightly lower than $0.15 \mathrm{~J} / \mathrm{m}^{2}$ of MX type $\mathrm{CrN}$, which precipitates as a primary nitride in steels with low $(<0.1 \mathrm{wt} \%)$ nitrogen contents [37-39]. In the present steel, the nitrogen content of $0.15 \mathrm{wt} \%$ was somewhat higher, although not very high. It is seen that in the instance of bulk nucleation, the $0.01 \mathrm{wt} \%$ of $\mathrm{Cr}_{2} \mathrm{~N}$ has formed within $8 \mathrm{~s}$ at $750{ }^{\circ} \mathrm{C}$, and after $90 \mathrm{~s}$ the amount is $1 \mathrm{wt} \%$. This means that some precipitation has already occurred within $10 \mathrm{~s}$, but the precipitation of all $0.15 \mathrm{wt} \%$ of $\mathrm{N}$ takes longer than $100 \mathrm{~s}$ at this temperature.

As seen in Figure 1, the stability of the 900/1 structure decreased gradually with prolonged annealing at $750{ }^{\circ} \mathrm{C}$ from 10 to $1000 \mathrm{~s}$, which was consistent with the predicted kinetics of the precipitation. Furthermore, according to the TTP-curves, annealing at higher temperatures of $800^{\circ} \mathrm{C}$ and $850{ }^{\circ} \mathrm{C}$ for $100 \mathrm{~s}$ formed $1 \mathrm{wt} \%$ and $0.01-0.1 \mathrm{wt} \%$ of $\mathrm{Cr}_{2} \mathrm{~N}$, respectively. Also, these results were in good agreement with the observation that the decline in the stability of the $900 / 1$ structure was considerable after $100 \mathrm{~s}$ annealing at $800{ }^{\circ} \mathrm{C}$ but marginal due to annealing at $850{ }^{\circ} \mathrm{C}$ (Figure $1 \mathrm{~b}$ ). From the TTP-curves we can conclude that no precipitation would take place at $900{ }^{\circ} \mathrm{C}$ within reasonable time, although the predicted equilibrium diagram in Figure 6 suggests that nitrides could exist in the structure at $900^{\circ} \mathrm{C}$.

Rajasekhara et al. [24,25] reported that very fast precipitation took place in a cold-rolled 301LN steel at $900-600{ }^{\circ} \mathrm{C}$, so that nano-size particles of the face-centered cubic phase of $\mathrm{CrN}$ were present in reversed ultrafine-grained austenite. The precipitation at $900{ }^{\circ} \mathrm{C}$ was less than that at lower temperatures. We have to notice that this precipitation occurred in cold-deformed martensite, so that the rate was much faster than in the present treatments where soft fully austenitic structure was annealed. Because of those previous extensive examinations, we did not want to repeat them, but only checked the presence of precipitates after the 900/1-750/1000 treatment. 


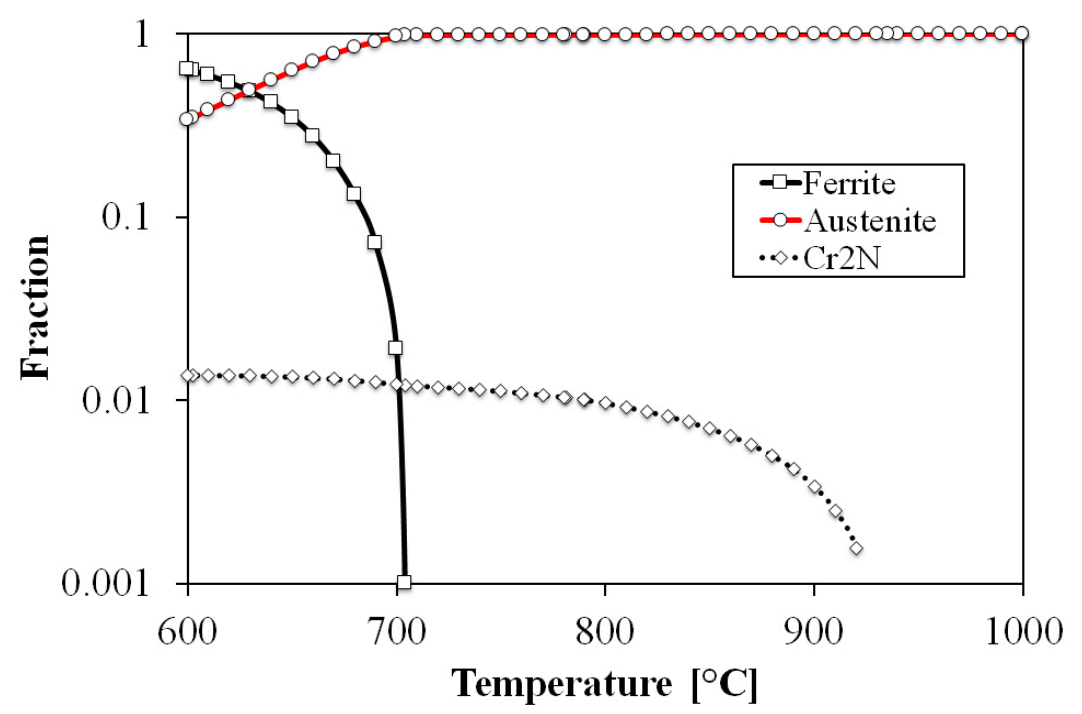

Figure 6. The predicted equilibrium diagram (major phases) for the 301LN steel indicating the precipitation of $\mathrm{Cr}_{2} \mathrm{~N}$ at temperatures below $920^{\circ} \mathrm{C}$.

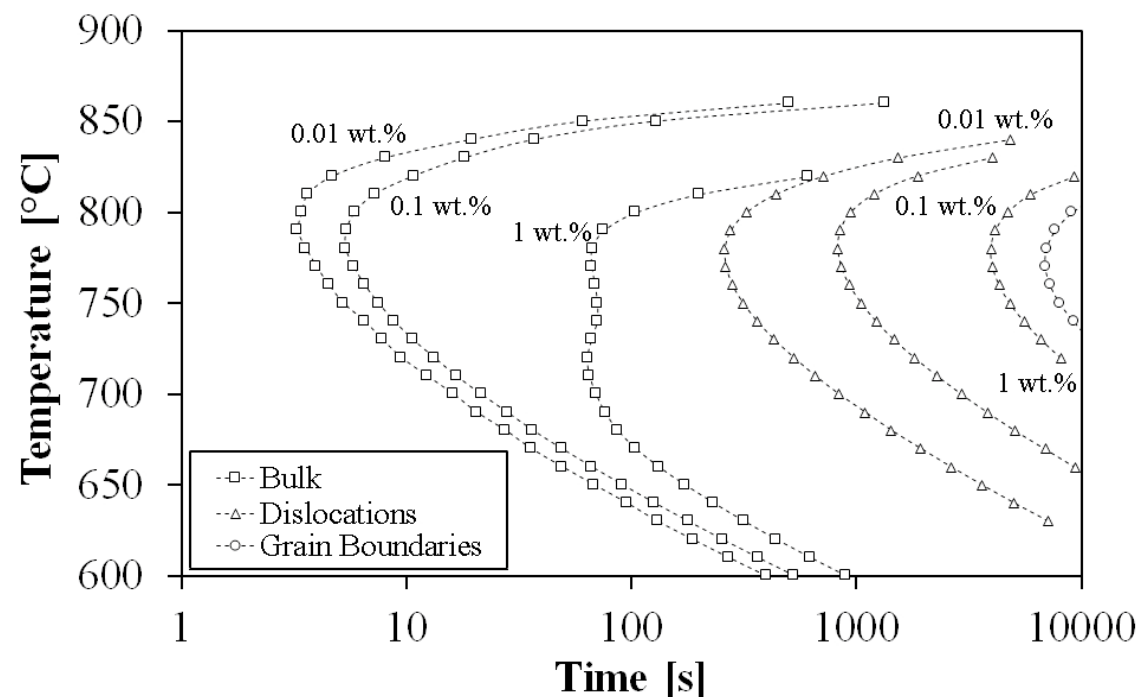

Figure 7. Time-temperature-precipitation curves (TTP-curves) showing the kinetics of $\mathrm{Cr}_{2} \mathrm{~N}$ precipitation at various temperatures (wt \% of precipitates in the structure). Nucleation assumed in bulk, on dislocations or grain boundaries.

\subsection{STEM Examination of Precipitates}

In addition to the above calculations, the microstructure of the 900/1-750/1000 structure was investigated in a STEM for finding a direct evidence on the precipitation. Figures 8 and 9 show typical precipitate particles and their distributions inside austenite grains, as observed in this sample. The size of the particles appeared to be between 5 and $35 \mathrm{~nm}$. Precipitates appeared in sparse clusters or in rows, as seen in Figures $8 \mathrm{a}$ and $9 \mathrm{a}$, respectively. The precipitates can be assumed to have the trigonal crystal structure as determined by Lee et al. [40,41] and Li et al. [42] for $\mathrm{C}_{2} \mathrm{~N}$ in high-nitrogen steels. The lattice parameters $\mathrm{a}=0.4796-0.4805 \mathrm{~nm}$ and $\mathrm{c}=0.4470-0.4479 \mathrm{~nm}$ have been reported for these [40-42]. For the identification of the precipitate, Type $\mathrm{a}=0.4800 \mathrm{~nm}$ and $\mathrm{c}=0.4477 \mathrm{~nm}$ were adopted. In diffraction patterns, the Miller-indices were used. A diffraction pattern in Figure $8 \mathrm{~b}$ acquired by nanobeam diffraction from a particle suggested that precipitates were of the $\mathrm{Cr}_{2} \mathrm{~N}$ type. Precipitates were rich in Cr, as seen in the EDS map (Figure 9b) of the area shown in Figure 9a. 

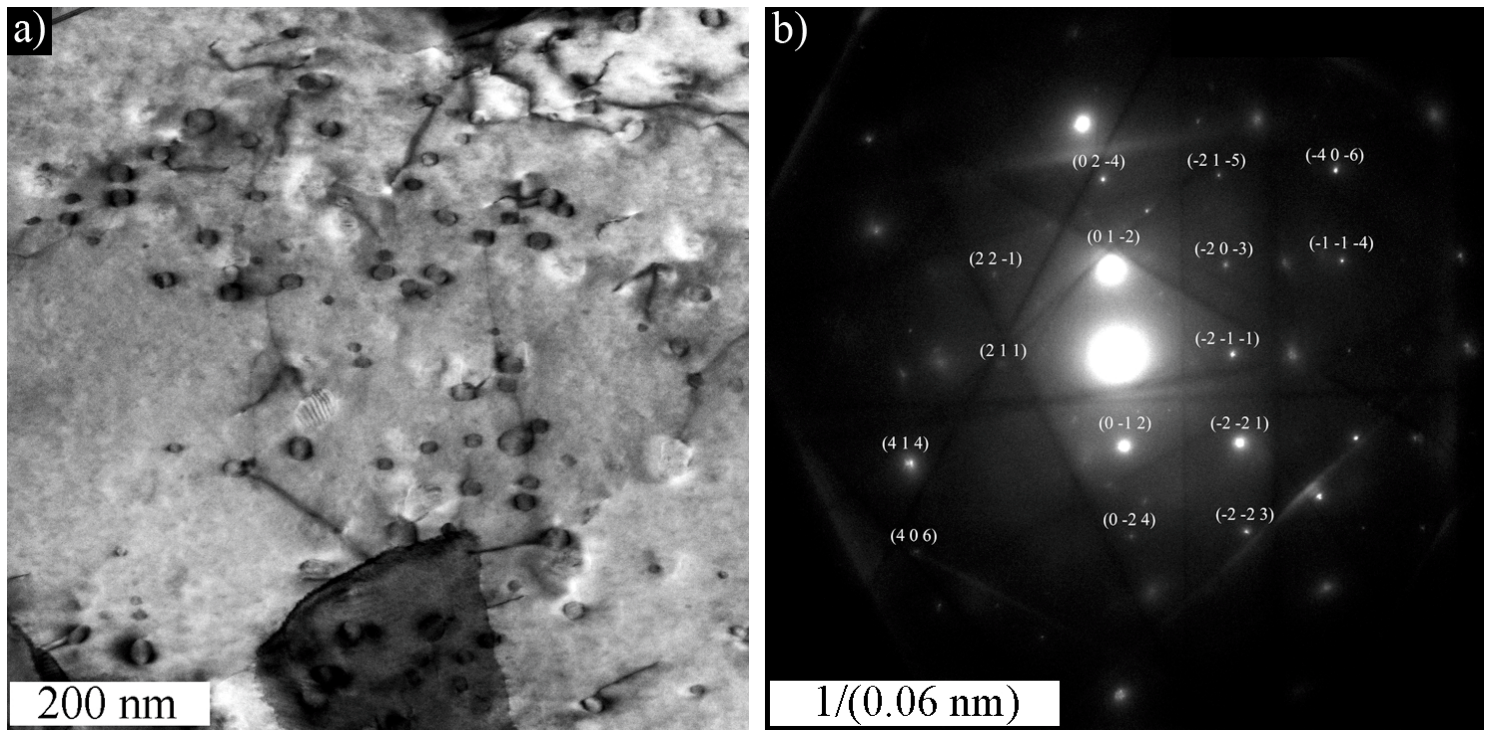

Figure 8. Precipitates in the 900/1-750/1000 structure inside a grain (a) and a nanobeam diffraction pattern showing the presence of a $\mathrm{Cr}_{2} \mathrm{~N}$ type particle (b). The zone [472].
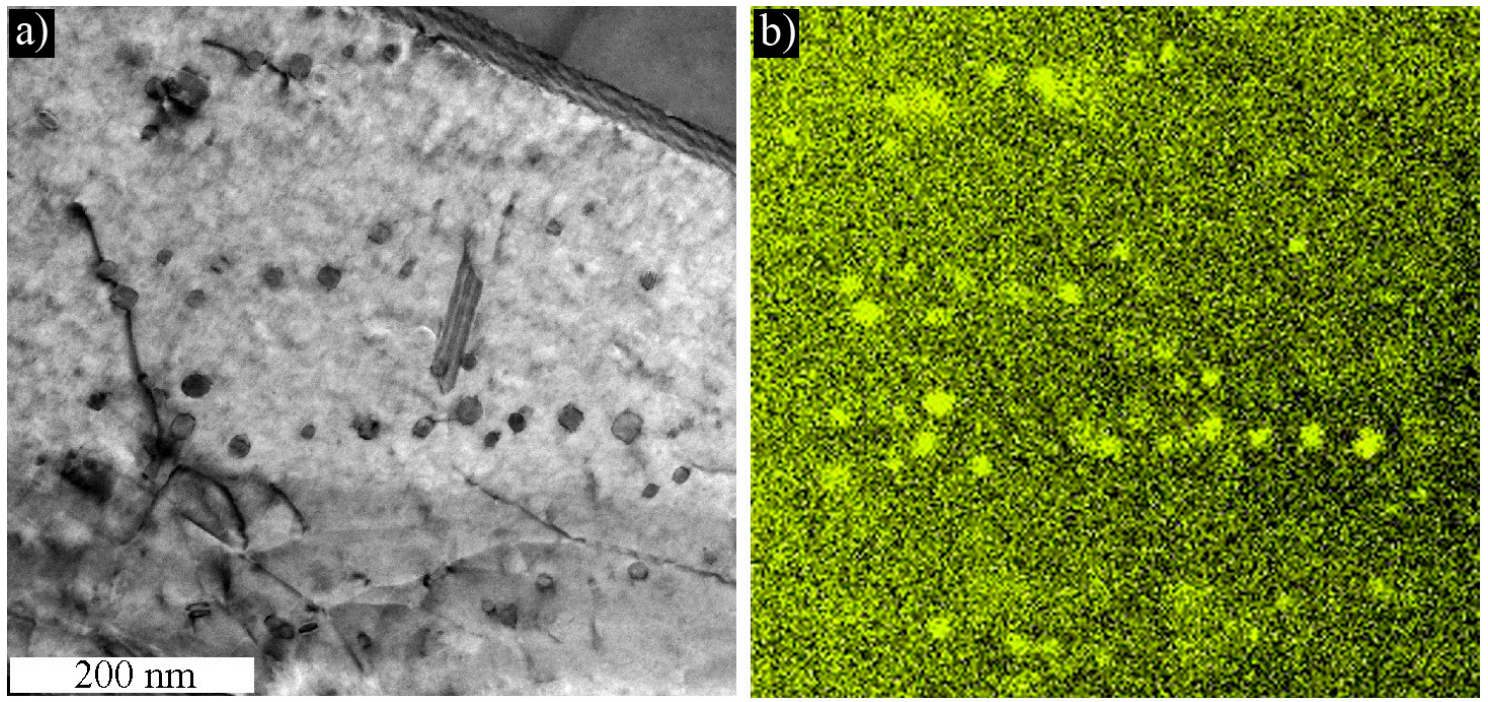

Figure 9. Precipitates after the 900/1-750/1000 treatment in rows (a) and the distribution of $\mathrm{Cr}$ (b).

\subsection{Completing Remarks}

The stability of the nitrogen-alloyed austenite will decrease if the nitrogen is bound in precipitates. Concerning the mechanism behind the stability change, it is understood that the austenite stability decreases with decreasing stacking fault energy (SFE). A low SFE implies that stacking faults can readily be formed in the austenite, so it can be expected that a low SFE promotes the presence of $\varepsilon$-martensite, which can act a nucleation site for $\alpha^{\prime}$-martensite [31,43]. The influence of nitrogen on the SFE of austenite in austenitic stainless steel seems to be complex, and contradictory experimental results have been reported, as discussed by Yabuktsov et al. [44]. They predicted in accordance with some data that at low nitrogen levels (up to $0.4 \mathrm{wt} \%$ ) SFE will increase with increasing nitrogen level and decrease at higher levels. Thus, binding the nitrogen would result in a lowered SFE and decreased stability.

In summary, we have now given direct evidence of the presence of $\mathrm{Cr}$-rich precipitates in the fine-grained austenite of Type 301LN N-bearing steel after annealing for $1000 \mathrm{~s}$ at $750{ }^{\circ} \mathrm{C}$. The predicted 
kinetics of $\mathrm{Cr}_{2} \mathrm{~N}$ precipitation matches well with the gradual marked changes recorded in the fraction of deformation-induced $\alpha^{\prime}$-martensite at a given tensile strain after various annealing durations. Thus we can firmly conclude that the nitride precipitation during annealing occurred at temperatures of $750-850{ }^{\circ} \mathrm{C}$, and it reduced the mechanical stability of the fine-grained austenitic structure in this steel and very slightly increased its yield strength. From this, we can argue that the precipitation is the factor reducing significantly the stability of reversion-treated submicron-grained structures while being formed at $700-800{ }^{\circ} \mathrm{C}$, compared to the stability of the fine-grained structure formed at $900{ }^{\circ} \mathrm{C}$. A refined grain size tends to increase the austenite stability in all structures, but this influence is overwhelmed by precipitation.

As a potential advantage, due to low mechanical stability, the yield strength of ultrafine-grained or partially reversed 301LN steel sheets can be effectively improved further by slight cold rolling thickness reduction (temper rolling). Preliminary experiments indicate that a $20 \%$ reduction results in the formation of about 35\% DIM, and thereby in a 25\% increase of the yield strength (close to $1000 \mathrm{MPa}$, i.e., about three times higher than the yield strength of a coarse-grained counterpart) while the elongation is still almost $30 \%$.

\section{Conclusions}

The work was aimed at verifying that nitride precipitation, instead of a submicron grain size, is the factor for strongly reducing the mechanical stability of grain-refined austenitic structures obtained by reversion annealing at temperatures of $700-800{ }^{\circ} \mathrm{C}$ in $301 \mathrm{LN}$ steel. In order to confirm this, the influence of subsequent low-temperature annealing (at 750-850 ${ }^{\circ} \mathrm{C}$ for $10-1000 \mathrm{~s}$ ) on the high stability of the fine-grained austenitic structure, obtained by reversion annealing at $900{ }^{\circ} \mathrm{C}$ in $1 \mathrm{~s}$, was investigated under tensile straining. The microstructure evolution was examined by EBSD and STEM, and the kinetics of precipitation was modeled. The main results are as follows:

- Low-temperature annealing at $750{ }^{\circ} \mathrm{C}$ for $10-1000 \mathrm{~s}$ gradually decreased gradually the stability of the fine-grained structure down to a low stability level for the ultrafine-grained structure created at $800{ }^{\circ} \mathrm{C}$ within $1 \mathrm{~s}$.

- Grain growth was minimal during these subsequent annealing treatments so that it did not cause the stability drop.

- Annealing at $750{ }^{\circ} \mathrm{C}$ for $1000 \mathrm{~s}$ resulted in slightly increased yield strength, long Luders elongation, and a reduced strain-hardening rate at small tensile strains, which seems to be typical of fine/nano-grained alloys containing fine precipitates.

- Modeling of the precipitation kinetics in annealed austenite indicates that $\mathrm{Cr}_{2} \mathrm{~N}$ precipitation started at $750{ }^{\circ} \mathrm{C}$ within $10 \mathrm{~s}$, and continued for longer than $100 \mathrm{~s}$. The predicted precipitation kinetics were in good agreement with the observed gradual reduction of austenite stability. The precipitation became much slower at $850^{\circ} \mathrm{C}$, and the corresponding stability change observed was minimal within $100 \mathrm{~s}$ annealing.

- Nano-sized particles identified as $\mathrm{Cr}_{2} \mathrm{~N}$ were found to exist inside austenite grains after $1000 \mathrm{~s}$ annealing at $750{ }^{\circ} \mathrm{C}$.

- It is very likely that the precipitation is the factor decreasing the mechanical stability of reversion-treated submicron-sized austenitic structures while they are being formed at $800-700{ }^{\circ} \mathrm{C}$ in 301LN nitrogen bearing steel.

Acknowledgments: Antti Järvenpää acknowledges with gratitude the funding from Technology Industries of Finland Centennial Foundation Fund for the Association of Finnish Steel and Metal Producers and the Interreg Nord 2014-2020 program, as well as the continuous support from Outokumpu Stainless Oy.

Author Contributions: Antti Järvenpää was responsible for mechanical testing, metallographic examinations, and data analysis. Matias Jaskari was responsible for metallographic and mechanical sample preparation, and conducting the texture analysis. Timo Juuti conducted the thermodynamic modeling for prediction the equilibrium phase diagram and the kinetics of the nitride precipitation in the steel. Pentti Karjalainen was the main author in writing the manuscript and drawing the conclusions. 
Conflicts of Interest: The authors declare no conflict of interest.

\section{References}

1. Fahr, D. Stress- and strain-induced formation of martensite and its effects on strength and ductility of metastable austenitic stainless steels. Mater. Trans. 1971, 2, 1883-1892.

2. Padilha, A.F.; Plaut, R.L.; Rios, P.R. Annealing of cold-worked austenitic stainless steels. ISIJ Int. 2003, 43, 135-143. [CrossRef]

3. Lo, K.H.; Shek, C.H.; Lai, J.K.L. Recent developments in stainless steels. Mater. Sci. Eng. R 2009, 65, 39-104. [CrossRef]

4. Stolarz, J.; Baffie, N.; Magnin, T. Fatigue short crack behaviour in metastable austenitic stainless steels with different grain sizes. Mater. Sci. Eng. A 2001, 319, 521-526. [CrossRef]

5. Pereloma, E.; Gazder, A.; Timokhina, I. Retained austenite: Transformation-induced plasticity. In Encyclopedia of Iron, Steel, and Their Alloys; Taylor \& Francis: New York, NY, USA, 2015; pp. 3088-3103.

6. De Knijf, D.; Nguyen-Minh, T.; Petrov, R.H.; Kestens, L.A.I.; Jonas, J.J. Orientation dependence of the martensite transformation in a quenched and partitioned steel subjected to uniaxial tension. J. Appl. Cryst. 2014, 47, 1261-1266. [CrossRef]

7. De Diego-Calderón, I.; Rodriguez-Calvillo, P.; Lara, A.; Molina-Aldareguia, J.M.; Petrov, R.H.; De Knijf, D.; Sabirov, I. Effect of microstructure on fatigue behavior of advanced high strength steels produced by quenching and partitioning and the role of retained austenite. Mater. Sci. Eng. A 2015, 641, 215-224. [CrossRef]

8. Das, A.; Tarafder, S.; Chakraborti, P.C. Estimation of deformation induced martensite in austenitic stainless steels. Mater. Sci. Eng. A 2011, 529, 9-20. [CrossRef]

9. Simmons, J.W. Overview: High-nitrogen alloying of stainless steels. Mater. Sci. Eng. A 1996, 207, 159-169. [CrossRef]

10. Machado, I.F.; Carvalho, P.A.; Padilha, A.F. Austenite instability and precipitation behavior of high nitrogen stainless steels. In Stainless Steel: Microstructure, Mechanical Properties and Methods of Application; Pramanik, A., Kumar Basak, A., Eds.; Nova Science Publishers: New York, NY, USA, 2015; pp. 1-36.

11. Nohara, K.; Ono, Y.; Ohashi, N. Composition and grain size dependencies of strain-induced martensitic transformation in metastable austenitic stainless steels. J. Iron Steel Inst. Jpn. 1977, 63, 212-222. [CrossRef]

12. Angel, T. Formation of martensite in austenitic stainless steels. J. Iron Steel Inst. 1954, 177, 165-174.

13. Lee, T.-H.; Oh, C.-S.; Kim, S.-J. Effects of nitrogen on deformation-induced martensitic transformation in metastable austenitic Fe-18Cr-10Mn-N steels. Scr. Mater. 2008, 58, 110-113. [CrossRef]

14. Simmons, J.W.; Covino, B.S.; Hawk, J.A.; Dunning, J.S. Effect of nitride $\left(\mathrm{Cr}_{2} \mathrm{~N}\right)$ precipitation on the mechanical, corrosion, and wear properties of austenitic stainless steel. ISIJ Int. 1996, 36, 846-854. [CrossRef]

15. Leal, R.H.; Guimaraes, J.R.C. Microstructure evolution during mechanically induced martensitic transformation in Fe-31\% Ni-0.1\% C. Mater. Sci. Eng. 1981, 48, 249-254. [CrossRef]

16. Varma, S.K.; Kalyanam, J.; Murr, L.E.; Srinivas, V. Effect of grain size on deformation-induced martensite formation in 304 and 316 stainless steels during room temperature tensile testing. J. Mater. Sci. Lett. 1994, 13, 107-111. [CrossRef]

17. Järvenpää, A.; Jaskari, M.; Man, J.; Karjalainen, L.P. Austenite stability in reversion-treated structures of a 301LN steel under tensile loading. Mater. Charact. 2017, 127, 12-26. [CrossRef]

18. Järvenpää, A.; Jaskari, M.; Man, J.; Karjalainen, L.P. Stability of grain-refined reversed structures in a 301LN austenitic stainless steel under cyclic loading. Mater. Sci. Eng. A 2017, 703, 280-292. [CrossRef]

19. Maréchal, D. Linkage between Mechanical Properties and Phase Transformation in a 301LN Austenitic Stainless Steel. Ph.D. Thesis, The University of British Columbia, Vancouver, BC, Canada, 2011.

20. Somani, M.C.; Juntunen, P.; Karjalainen, L.P.; Misra, R.D.K.; Kyröläinen, A. Enhanced mechanical properties through reversion in metastable austenitic stainless steels. Metall. Mater. Trans. A 2009, 40, 729-744. [CrossRef]

21. Kisko, A.; Misra, R.D.K.; Talonen, J.; Karjalainen, L.P. The influence of grain size on the strain-induced martensite formation in tensile straining of an austenitic $15 \mathrm{Cr}-9 \mathrm{Mn}-\mathrm{Ni}-\mathrm{Cu}$ stainless steel. Mater. Sci. Eng. A 2013, 578, 408-416. [CrossRef] 
22. Behjati, P.; Kermanpur, A.; Najafizadeh, A.; Samaei Baghbadorani, H. Effect of annealing temperature on nano/ultrafine grain of Ni-free austenitic stainless steel. Mater. Sci. Eng. A 2014, 592, 77-82. [CrossRef]

23. Shi, F.; Wang, L.J.; Cui, W.F.; Liu, C.M. Precipitation kinetics of $\mathrm{Cr}_{2} \mathrm{~N}$ in high nitrogen austenitic stainless steel. J. Iron Steel Res. Int. 2008, 15, 72-77. [CrossRef]

24. Rajasekhara, S.; Karjalainen, L.P.; Kyröläinen, A.; Ferreira, P.J. Microstructure evolution in nano/submicron grained AISI 301LN stainless steel. Mater. Sci. Eng. A 2010, 527, 1986-1996. [CrossRef]

25. Rajasekhara, S.; Ferreira, P.J.; Karjalainen, L.P.; Kyröläinen, A. Hall-Petch behavior in ultra-fine-grained AISI 301LN stainless steel. Met. Mater. Trans. A 2007, 38, 1202-1210. [CrossRef]

26. Lee, S.-J.; Park, Y.-M.; Lee, Y.-K. Reverse transformation mechanism of martensite to austenite in a metastable austenitic alloy. Mater. Sci. Eng. A 2009, 515, 32-37. [CrossRef]

27. Kisko, A.; Rovatti, L.; Misra, D.; Puspendu, S.; Talonen, J.; Karjalainen, L.P. Studies on martensite transformation in a metastable austenitic Cr-Mn stainless steel. Mater. Sci. Forum 2013, 762, 424-430. [CrossRef]

28. Castro Cerda, F.M.; Kestens, L.A.I.; Monsalve, A.; Petrov, R.H. The effect of ultrafast heating in cold-rolled low carbon steel: Recrystallization and texture evolution. Metals 2016, 6, 288. [CrossRef]

29. Beese, A.M.; Mohr, D. Identification of the direction-dependency of the martensitic transformation in stainless steel using in situ magnetic permeability measurements. Exp. Mech. 2011, 51, 667-676. [CrossRef]

30. Talonen, T.; Aspegren, P.; Hänninen, H. Comparison of different methods for measuring strain induced $\alpha^{\prime}$-martensite content in austenitic steels. Mater. Sci. Technol. 2004, 20, 1506-1512. [CrossRef]

31. Talonen, J. Effect of Strain-Induced $\alpha^{\prime}$-Martensite Transformation on Mechanical Properties of Metastable Austenitic Stainless Steels. Ph.D. Thesis, Helsinki University of Technology, Espoo, Finland, 2007.

32. Järvenpää, A.; Karjalainen, L.P.; Jaskari, M. Effect of grain size on fatigue behaviour of Type 301LN stainless steel. Int. J. Fatigue 2014, 65, 93-98. [CrossRef]

33. Precipitation Module (TC-PRISMA) User Guide Thermo-Calc Version 2017a; Thermo-Calc Software AB: Solna, Sweden, 2017.

34. Song, R.; Ponge, D.; Raabe, D.; Speer, J.G.; Matlock, D.K. Overview of processing, microstructure and mechanical properties of ultrafine grained bcc steels. Mater. Sci. Eng. A 2006, 441, 1-17. [CrossRef]

35. Lee, T.; Park, C.H.; Lee, D.-L.; Lee, C.S. Enhancing tensile properties of ultrafine-grained medium-carbon steel utilizing fine carbides. Mater. Sci. Eng. A 2011, 528, 6558-6564. [CrossRef]

36. Wang, Z.C.; Prangnell, P.B. Microstructure refinement and mechanical properties of severely deformed Al-Mg-Li alloys. Mater. Sci. Eng. A 2002, 328, 87-97. [CrossRef]

37. Xu, W.; San Martin, D.; Riverta Diaz del Castillo, P.E.J.; Van der Zwaag, S. Modelling and characterization of Chi phase grain boundary precipitation during aging of Fe-Cr-Ni-Mo stainless steel. Mater. Sci. Eng. A 2007, 467, 24-32. [CrossRef]

38. Ouden, D.; Vermolen, F.J.; Zhao, L.; Vuik, C.; Sietsma, J. Mathematical modelling of NbC particle nucleation and growth in an HSLA steel under elastic deformation. Solid State Phenom. 2011, 172-174, 893-898. [CrossRef]

39. Padilha, A.F.; Rios, P.R. Decomposition of austenite in austenitic stainless steels. ISIJ Int. 2002, 42, 325-337. [CrossRef]

40. Lee, T.-H.; Ha, H.-Y.; Kim, S.-J. Precipitation of second phases in high-interstitial-alloyed austenitic steel. Metall. Mater. Trans. A 2011, 42, 3543-3548. [CrossRef]

41. Lee, T.-H.; Oh, C.-S.; Han, H.N.; Lee, C.G.; Kim, S.-J.; Takaki, S. On the crystal structure of $\mathrm{Cr}_{2} \mathrm{~N}_{\text {precipitates }}$ in high-nitrogen austenitic stainless steel. Acta Cryst. 2005, B61, 137-144. [CrossRef] [PubMed]

42. Li, J.-Y.; Liu, H.-N.; Huang, P.-W. Effects of pre-precipitation of $\mathrm{Cr}_{2} \mathrm{~N}$ on microstructures and properties of high nitrogen stainless steel. J. Cent. South Univ. 2012, 19, 1189-1195. [CrossRef]

43. Talonen, J.; Hanninen, H. Formation of shear bands and strain-induced martensite during plastic deformation of metastable austenitic stainless steels. Acta Mater. 2007, 55, 6108-6118. [CrossRef]

44. Yabuktsov, I.A.; Ariapour, A.; Perovic, D.D. Effect of nitrogen on stacking fault energy of f.c.c. iron-based alloys. Acta Mater. 1999, 47, 1271-1279.

(C) 2017 by the authors. Licensee MDPI, Basel, Switzerland. This article is an open access article distributed under the terms and conditions of the Creative Commons Attribution (CC BY) license (http:/ / creativecommons.org/licenses/by/4.0/). 